\title{
CAT (FELIS CATUS L.) SPERMATOZOA REQUIRE CAPACITATION
}

\author{
G. E. HAMNER, L. L. JENNINGS AND N. J. SOJKA \\ Division of Reproductive Biology, Department of Obstetrics and Gynecology, \\ University of Virginia Medical School, Charlottesville, Virginia 22901, U.S.A.
}

(Received 23rd Fanuary 1970)

\begin{abstract}
Summary. In the oestrous female cat, fertilization can take place when spermatozoa are introduced into the vagina up to $49 \mathrm{hr}$ after an ovulation-inducing injection of human chorionic gonadotrophin. The spermatozoa require residence in the female reproductive tract before they are capable of fertilizing the eggs in vitro. No eggs were fertilized by freshly ejaculated spermatozoa. One of four oestrous females was able to prepare spermatozoa to fertilize eggs in vitro after $\frac{1}{2}$ to $1 \mathrm{hr}$ incubation of spermatozoa in utero. All oestrous females' uteri rendered the spermatozoa capable of fertilizing eggs in vitro after 2- to 24-hr incubation. Sixty-one eggs were cultured in vitro with spermatozoa incubated in utero for 2 to $24 \mathrm{hr}$, resulting in $62 \%$ of the eggs being fertilized.
\end{abstract}

\section{INTRODUCTION}

Chang (1951) discovered that rabbit spermatozoa needed to reside for a minimum period in the reproductive tract of the doe before they were capable of fertilizing the eggs. This observation has been confirmed many times and is called 'capacitation' (Austin, 1952). The period of incubation required for capacitation of rabbit spermatozoa is 6 to $11 \mathrm{hr}$ in the oestrous doe (Chang, 1951; Bedford, 1969).

The cat, like the rabbit, is an induced ovulator but the cat does not ovulate until $25 \frac{1}{2} \mathrm{hr}$ after mating, whereas the rabbit ovulates within $10 \mathrm{hr}$ of mating. At present, it is not known whether capacitation of cat spermatozoa is required and if required, whether the time needed for incubation is similar to or quite different from that for the rabbit. This paper reports the results of fertilization experiments designed to answer these two questions.

\section{MATERIALS AND METHODS}

Mature, random-bred, male and female cats were used throughout this study. The cats were maintained in a controlled environment $\left(21 \pm 2^{\circ} \mathrm{C}\right.$ with $50 \mathrm{ft}$ candles of light provided at the cage level for $14 \mathrm{hr}$ per day) for at least 3 weeks before experimentation. Unrestricted access to Purina cat chow and fresh water were provided. 
Semen was collected by artificial vagina from trained male cats (Sojka, Jennings \& Hamner, 1970). The semen was diluted with warm saline $(0.9 \%$ $\mathrm{NaCl}$ ) to contain 20 to $100 \times 10^{6}$ spermatozoa/ml. Sperm numbers (using a haemocytometer) and motility were determined with a light microscope.

Oestrus was detected in the females by their behaviour and the characteristics of their vaginal smears (Scott, 1967). Queens in natural full oestrus were stimulated to ovulate by injecting 50 i.u. of human chorionic gonadotrophin (HCG) intramuscularly (Follutein, E. R. Squibb and Sons). Superovulation was obtained by injecting the pro-oestrous female with $150 \mathrm{i}$.u. of pregnant mare serum intraperitoneally (Gestyl, Organon Laboratories), followed $72 \mathrm{hr}$ later by 50 i.u. of HCG. Ovulation began $25 \frac{1}{2}$ to $26 \mathrm{hr}$ after HCG injection (Sojka et al., 1970). Eggs were recovered from the oviducts by cannulating the isthmus with a 23-gauge needle and flushing with $2 \mathrm{ml}$ of warm saline.

Incubation of the spermatozoa was accomplished by injecting $0.1 \mathrm{ml}$ of suspended spermatozoa into the uterine horn of a surgically prepared female. Spermatozoa were recovered by flushing the uterus with warm culture media and then withdrawing the media into a syringe.

The fertilization studies in vitro were carried out using a very similar system to the one perfected by Brackett \& Williams (1968) for rabbit eggs. Eggs were recovered from the oviduct of a superovulated queen $30 \mathrm{hr}$ after injection of HGG. The eggs were washed in saline and transferred to a culture dish which could be sealed, containing Brackett's medium (Brackett, 1970) under mineral oil. The spermatozoa were recovered from the uterine incubation in Brackett's medium and added to the egg culture $\left(15\right.$ to $75 \times 10^{5}$ spermatozoa $\left./ \mathrm{ml}\right)$. The spermatozoa and eggs were cultured together in the dark at $37^{\circ} \mathrm{C}$, under a $5 \% \mathrm{CO}_{2}$-air atmosphere for $18 \mathrm{hr}$. After $18 \mathrm{hr}$ incubation, the eggs were transferred to heated rabbit blood serum and cultured for a further 8 to $24 \mathrm{hr}$ at $37^{\circ} \mathrm{C}$, under oil in the dark. The eggs were then examined by phase contrast microscopy for fertilization and normal cleavage.

\section{RESULTS}

The first series of experiments was designed to determine the length of time that could be allowed to elapse between the injection of an oestrous female with HGG and subsequent mating, for fertilization to take place. Successful mating occurred up to $49 \mathrm{hr}$ after injection of HCG but no fertilized eggs were recovered from matings that occurred $50 \mathrm{hr}$ or later after $\mathrm{HGG}$ injection, i.e. approximately $24 \mathrm{hr}$ after ovulation (Table 1).

Using the information gained from the delayed mating experiments and the experience of Chang (1951) with rabbits, an attempt was made to develop an assay in vivo to determine if capacitation is needed in the cat. One complete assay was performed by incubating spermatozoa in the uterus of an oestrous cat for $24 \mathrm{hr}$ and then inseminating freshly ejaculated spermatozoa into the right oviducts and transferring the incubated spermatozoa to the left oviducts of two oestrous cats (egg donors) given HCG $50 \mathrm{hr}$ earlier. The freshly ejaculated spermatozoa did not fertilize any of the three eggs recovered but the incubated spermatozoa fertilized two of four eggs, though the fertilized eggs appeared to 
be degenerating. This assay approach was abandoned because it was felt that the eggs were nearing the end of the period during which they were fully capable of being fertilized before the spermatozoa could be introduced. Since fertilized eggs were obtained when mating occurred $49 \mathrm{hr}$, but not $50 \mathrm{hr}$, after HCG injection, the capacitation time must be short if the eggs lose their ability to be fertilized approximately $50 \mathrm{hr}$ after HCG injection.

TABLE 1

FERTILIZATION OF CAT EGGS AFTER NORMAL AND DELAYED MATING

\begin{tabular}{c|ccc}
\hline \multirow{2}{*}{$\begin{array}{c}\text { Mating time } \\
\text { (hr post HCG })^{*}\end{array}$} & \multicolumn{3}{|c}{ No. of eggs recovered } \\
\cline { 2 - 4 } & Total & Fertilized & $\%$ Fertilized \\
\hline 0 & 14 & 12 & 86 \\
12 & 5 & 5 & 100 \\
18 & 7 & 4 & 57 \\
21 & 2 & 2 & 100 \\
24 & 3 & 3 & 100 \\
27 & 4 & 4 & 100 \\
30 & 6 & 4 & 67 \\
33 & 3 & 1 & 33 \\
36 & 8 & 7 & 88 \\
39 & 6 & 4 & 67 \\
42 & 4 & 3 & 75 \\
49 & 2 & 1 & 50 \\
50 & 3 & 0 & 0 \\
52 & 7 & 0 & 0 \\
55 & 6 & 0 & 0 \\
\hline
\end{tabular}

* Ovulation occurs $25 \frac{1}{2}$ to $26 \mathrm{hr}$ after injection of 50 i.u. of HCG.

TABLE 2

FERTILIZATION OF CAT EGGS in vitro BY SPERMATOZOA INGUBATED in utero

\begin{tabular}{|c|c|c|c|c|}
\hline \multirow[b]{2}{*}{ Incubation time } & \multirow{2}{*}{$\begin{array}{l}\text { No. of } \\
\text { experiments }\end{array}$} & \multicolumn{3}{|c|}{ No. of eggs cultured } \\
\hline & & Total & Cleaved & $\%$ Cleaved \\
\hline $\begin{array}{l}\text { Not incubated (no spermatozoa) } \\
\text { Not incubated (freshly ejaculated spermatozoa) }\end{array}$ & $\begin{array}{l}3 \\
5\end{array}$ & $\begin{array}{r}9 \\
22\end{array}$ & $\begin{array}{l}0 \\
0\end{array}$ & $\begin{array}{l}0 \\
0\end{array}$ \\
\hline $\begin{array}{l}\text { Incubated for } \\
\quad 0.5 \mathrm{hr} \\
0.5 \mathrm{hr} \\
0.5 \mathrm{hr} \\
1.0 \mathrm{hr} \\
2.0 \mathrm{hr} \\
4.0 \mathrm{hr} \\
6.5 \mathrm{hr} \\
24.0 \mathrm{hr}\end{array}$ & $\begin{array}{l}1 \\
1 \\
1 \\
1 \\
3 \\
1 \\
1 \\
1\end{array}$ & $\begin{array}{r}8 \\
8 \\
7 \\
8 \\
30 \\
3 \\
9 \\
19\end{array}$ & $\begin{array}{r}6 \\
0 \\
0 \\
0 \\
16 \\
2 \\
3 \\
17\end{array}$ & $\begin{array}{r}75 \\
0 \\
0 \\
0 \\
53 \\
67 \\
33 \\
90\end{array}$ \\
\hline
\end{tabular}

We decided to turn to a fertilization system in vitro that would allow the use of recently ovulated eggs cultured with spermatozoa incubated in the uterus of oestrous females for $\frac{1}{2}$ to $24 \mathrm{hr}$ before culturing them with eggs recovered from superovulated females $30 \mathrm{hr}$ after injection of HGG. There was no cleavage of any egg cultured without spermatozoa or with freshly ejaculated spermatozoa. 
One of three oestrous females was able to render the spermatozoa capable of fertilizing eggs within $\frac{1}{2} \mathrm{hr}$ of uterine incubation, while another cat was unable to capacitate spermatozoa in $1 \mathrm{hr}$. All oestrous cats were able to capacitate spermatozoa incubated in utero for 2 to $24 \mathrm{hr}$. One cat that did not capacitate the spermatozoa in her right uterine horn in $\frac{1}{2} \mathrm{hr}$, provided spermatozoa from her left uterine horn that were capable of fertilizing eggs after $2 \mathrm{hr}$ incubation (Table 2). A total of sixty-one eggs were cultured with spermatozoa that had been incubated in utero for 2 to $24 \mathrm{hr}$. Thirty-eight eggs, or $62 \%$ of the total, were fertilized. Fertilized eggs cultured in heated rabbit blood serum showed normal cleavage of up to sixteen cells by the 3rd day but then began to degenerate.

To our knowledge, this is the first report of fertilization of cat eggs in vitro. Experiments are planned to transfer similarly fertilized eggs to the oviducts of synchronized foster queens in an attempt to deliver normal offspring.

In two additional experiments, cat spermatozoa were incubated in follicular fluid and cumulus cells suspended in culture media in vitro for $2 \frac{1}{2}$ to $18 \mathrm{hr}$. These spermatozoa were unable to fertilize eggs.

\section{ACKNOWLEDGMENTS}

This study was supported by the Morris Animal Foundation and Grant HD03516 from the United States Public Health Service.

\section{REFERENCES}

Austin, C. R. (1952) The "capacitation" of the mammalian sperm. Nature, Lond. 170, 326.

BEDFORD, J. M. (1969) Limitations of the uterus in the development of the fertilizing ability (capacitation) of spermatozoa. J. Reprod. Fert., Suppl. 8, 19.

BRACKETT, B. G. (1970) In vitro fertilization of mammalian ova. In: Schering Symposium on Mechanisms Involved in Conception. Advances in the Biosciences, Vol. 4, p. 73. Ed. G. Raspe. Pergamon Press-Vieweg, New York.

Bracketr, B. G. \& Wiritams, W. L. (1968) Fertilization of rabbit ova in a defined medium. Fert. Steril. $19,144$.

Chang, M. C. (1951) Fertilizing capacity of spermatozoa deposited into the Fallopian tubes. Nature, Lond. 168, 697.

Scotr, P. P. (1967) The cat. In: UFAW Handbook on the Care and Management of Laboratory Animals, 3rd edn, pp. 505-567. Animal Welfare Institute, New York.

Sojka, N. J., Jennings, L. L. \& Hamner, G. E. (1970) Artificial insemination in the cat (Felis catus L.). Lab. Anim. Care, 20, 198. 